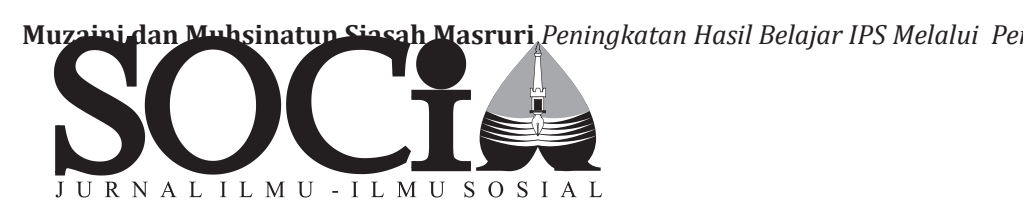

\title{
Peningkatan Hasil Belajar IPS melalui Penerapan PBL Berbantuan Powerpoint pada Siswa SMPN 1 Gemolong Kabupaten Sragen
}

\author{
MUZAINI DAN MUHSINATUN SIASAH MASRURI \\ SMPN 1 Gemolong Sragen, Universitas Negeri Yogyakarta \\ muzainisoetarto@yahoo.com,muhsinsiasah@gmail.com
}

\begin{abstract}
Abstrak
Penelitian ini bertujuan untuk meningkatkan: aktivitaspembelajaran IPS melalui penerapan problem based learning (PBL) berbantuan PowerPoint, dan hasil belajar IPS siswa SMPN 1 Ge molong Kabupaten Sragen.Jenis penelitian ini adalah penelitian tindakan kelas. Subjekpenelitian adalah siswa kelas VIIIC SMPN 1 Gemolong Kabupaten Sragen.Jenis tindakan yang diterapkan adalah pembelajaran dengan pendekatan PBL berbantuan powerpoint. Teknik pengumpulan data yang digunakan adalah dokumentasi, observasi, wawancara dan tes. Data dianalisis dengan statistik deskriptif. Analisis ini untuk menjelaskan perkembangan proses pembelajaran dan hasil belajar sebelum dan setelah diterapkan pembelajaran dengan PBL.Hasil penelitian ini menunjukkan bahwa setelah dilakukan tindakan pembelajaran dengan menerapkan PBL berbantuan powerpoint: 1) terjadi peningkatan aktivitas pembelajaran sebesar $57 \%$ pada siklus I, dan $5 \%$ pada siklus II; 2) terjadi peningkatan hasil belajar sebesar 57,58\% pada siklus I, dan 6,06\% pada siklus II; 3) terjadi peningkatan ketuntasan belajar sebesar 36,37\% pada siklus I, dan $12,12 \%$ pada siklus II; dan 4) peningkatan sikap dan keterampilan kerja sama kelompok sebesar 24,24\% pada siklus II.
\end{abstract}

Kata Kunci: hasil belajar, pembelajaran IPS, Problem Based Learning, media PowerPoint.

\begin{abstract}
The objectives of this research are: to improve social studies learning activities and social studies learning outcomes of Junior High School 1 Gemolong students, Sragen Regency through the implementation of problem basedlearning (PBL) assisted by PowerPoint. This research is classroom action research (CAR). The subjects of research were students of VIIIC Junior High School 1 Gemolong, Sragen regency. The actions applied were problem basedlearning approaches assisted by PowerPoint. The data were collectedby using documentations, observations, interviews, and tests. In this research, the data were analyzed using descriptive statistics technique. This analysis was used to describe the process and improvement of learning outcomes before and after the implementation of PBL assisted by PowerPoint. The results show that after the implementation of PBL assisted by powerpoint: 1) there is an improvement of social studies learning activities 57\% in Cycle I and it improved 5\% in Cycle II; and 2) there is an improvement of cognitive learning outcomes 57,58\% in Cycle I, and it improved 6,06\% in Cycle II; 3) there is an improvement of learning completeness $36,37 \%$ in Cycle I, and it improved 12,12\% in Cycle II; and 4) there is an improvement of attitude and teamwork skill 24,24\% in Cycle II.
\end{abstract}

Keywords: learning outcome, social studies learning, problem basedlearning, PowerPoint. 


\section{PENDAHULUAN}

Dalam kegiatan pembelajaran di kelas, guru diharapkan dapat melaksanakan tugas secara profesional, sehingga hasil belajar se suai yang diharapkan. Sesuai dengan yang termaktub dalam UndangUndang nomor 20 tahun 2003 tentang Sistem Pendidikan Nasional, bahwa kewajiban guru atau pendidik diatur dalam Pasal 40 ayat (2). Pasal itu menyebutkan bahwa pendidik dan tenaga kependidikan berkewajiban: menciptakan suasana pendidikan yang bermakna, menye nangkan, kreatif, dinamis, dan dialogis; serta mempunyai komitmen secara profesional untuk meningkatkan mutu pendidikan (Bidang Dikbud KBRI Tokyo, (tt), p. 13)

Pentingnya peranan guru juga diperkuat dengan Peraturan Pemerintah nomor 19 tahun 2005 tentang Standar Nasional Pendidikan. Seperti yang tertulis pada Pasal 28 ayat 3 dalam peraturan itu dijelaskan bahwa guru harus memiliki kompetensi sebagai agen pembelajaran pada jenjang pendidikan dasar dan menengah serta pendidikan anak usia dini, meliputi: kompetensi pedagogik, kompetensi kepribadian, kompetensi profesional; dan kompetensi sosial(Tambahan Lembaran Negara Republik Indonesia Nomor 4496,(tt): 21).

Karakteristik seorang guru profesional antara lain: (1) mampu memahami berbagai teori belajar; (2) menentukan strategi pembelajaran berdasarkan kondisi anak didik, kompetensi yang ingin dicapai, dan materi ajar yang disampaikan; dan (3) menyusun rancangan pembelajaran berdasarkan strategi yang telah dipilih (Wibowo, 2012: 111).

Di samping kompetensi guru yang perlu ditingkatkan, keterlibatan aktif siswa dalam pembelajaran juga sangat diperlukan dalam pencapaian tujuan pembelajaran. Dewasa ini, pendekatan pembelajaran diharapkan berubah dari teacher centered learning menjadi student center learning yang menekankan keterlibatan siswa dalam proses pembelajaran. Keterlibatan siswa tersebut salah satu kriteria pembelajaran pada abad ke21, Bentuk keterlibatan siswa tersebut meliputi: motivasidankomitmenbelajar; rasa memiliki danberprestasi; serta memiliki hubungandengan orang dewasa, teman sebaya, dan orang tuayang mendukungproses belajar (Jones, 2009: 2324).

Di satu pihak, guru harus meningkatkan kemampuannya dalam melaksanakan tugas profesionalnya, dan di pihak lain, siswa perlu meningkatkan diri dan terlibat aktif dalam pembelajaran.Jadi, upaya guru untuk mening katkan mutu pembelajaran perlu diimbangi dengan peningkatan keaktifan siswa dalam belajar, sehingga diharapkan tercapai tujuan pembelajaran.

Namun demikian, situasi ideal pembelajaran belum secara optimal dapat dilaksanakan. Guru belum mampu melaksanakan tugas secara profesional seperti yang diharapkan. Pada kenyataanya, guru masih mengalami berbagai masalah dalam pembelajaran. Salah satu masalah itu adalah masalah metodologis, yaitu masalah yang terkait dengan upaya atau proses pembelajaran meliputi kualitas penyampaian materi, kualitas interaksi antara guru dengan siswa, kualitas pemberdayaan sarana dan elemen dalam pembelajaran. Konsekuensinya guru harus memiliki kemampuan seni dalam menyampaikan materi pelajaran, mengetahui secara tepat kapan dan bagaimana menggunakan metode pembelajaran, serta memiliki kemampuan memilih dan menggunakan sarana pembelajaran (Muchith, 2008: 9).

Berdasarkan data yang ditemukan di lapangan bahwa guru belum melaksanakan pembelajaran dengan menggunakan pendekatan dan medote pembelajaran yang bervariasi sesuai dengan tujuan dan materi pembelajaran. Dalam pembelajaran, guru belum menerapkan pendekatan problem based learning dan juga belum menerapkan pendekatan student centered learning. Hal ini juga berpengaruh terhadap rendahnya aktivitas pembelajaran yang dilakukan baik oleh guru maupun siswa, serta rendahnya hasil belajar IPS. Kondisi tersebut terlihat pada rendahnya keaktifan siswa dalam kerja sama kelompok (teamwork) dan rendahnya nilai ulangan harian (aspek kognitif). Berdasarkan hasil nilai ulangan harian siswa SMP Negeri 1 Gemolong Kabupaten Sragen 
yang dilaksanakan pada tanggal 7 September 2013, terdapat bukti bahwa nilai siswa yang ada di bawah 70 atau termasuk kriteria kurang dan gagal mencapai $66,67 \%$.

Pembelajaran IPS dengan menerapkan problem based learning atau pembelajaran berbasis masalah merupakan salah satu jawa ban untuk memberikan solusi pemecahan masalah, khususnya meningkatkan peran dan keterlibatan siswa dalam pembelajaran. Melalui pembelajaran IPS, guru diharapkan dapat memberikan bekal keterampilan kepada siswa untuk menghadapi permasalahanpermasalahan dalam kehidupan nyata di masyarakat.Sebab, masalah pendidikan pada abad ke21 berhubungan dengan munculnya permasalahan baru yang terkait dengan dunia nyata.Pendekatan pembelajaran berbasis masalah dapat membekali siswa dalam penggunaan intelegensi dari dalam diri individu yang berada dalam sebuah kelompok orang, atau lingkungan untuk memecahkan masalah yang bermakna, relevan dan konteks tual (Rusman, 2012: 230).

Definisi PBL sebagai berikut: "PBL is an instructional (and curricular) learnercentered approach that empowers learners to conduct research, integrate theory and practice, and apply knowledge and skills to develop a viable solution to a defined problem"(Savery, 2006: 13). PBL adalah pendekatanpembelajaran (dan kurikulum)yang berpusatpada siswa untuk memberdayakansiswa melakukan penelitian, mengintegrasikan teoridan praktek, dan menerapkan pengetahuan dan kete rampilan untuk mengembangkans olusi yang layak untuk masalah yang didefinisikan.

Berdasarkan definisi tersebut dapat disimpulkan bahwa PBL merupakan sebuah pendekatan dalam pembelajaran yang me ngandung unsurunsur berpusat pada siswa (student centered learning), pembelajaran inquiry, menghubungkan teori dan kenyataan, serta memberikan siswa keterampilan peme cahan masalah.

Prinsipprinsippembelajaran PBL sebagai berikut: (a) PBL adalah pendekatan pendidikan yang masalahnya didasarkan pada masalah kehidupan nyata (reallife problems); (b) pembelajaran menggunakan prinsip par- ticipantdirected learning processes (proses partisipasi belajar mandiri), atau selfdirected learning(pembelajaran mandiri); (c) experience learning(belajar berdasarkan pengalaman); (d) pembelajaran berbasis aktivitas (activebased learning); (e) belajar Interdisi plin (interdisciplinary learning); (f) praktek teladan (exemplary practice); dan (f) pembelajaran berbasis kelompok (groupbased learning) (De Graaff \& Kolmos 2003: 658).

Di samping peran siswa yang aktif dalam pembelajaran, peran guru juga merupakan unsur utama dalam PBL.Pentingnya peran dapat diketahui dari lima fitur dalam PBL. Kelima fitur tersebut meliputi: (a) guru sebagai fasilitator; (b) penggunaan suatu proses eksplisit(proses tutorial) untuk memfasilitasi pembelajaran; (c) penggunaan "masalah"untuk merangsang, mengkontekstualisasikan dan mengintegrasikan pembelajaran; (d) belajar dalam kelompok kecil; dan (e) penilaian dalam PBL (Newman, 2005: 13).

Beberapa kelebihan metode PBL adalah sebagai berikut: (1) siswa akan terbiasa menghadapi masalah (problem posing) dan merasa tertantang untuk menyelesaikan masalah, tidak hanya terkait dengan pembelajaran dalam kelas, tetapi juga menghadapi masalah yang terjadi dalam kehidupan seharihari (real world); (2) memupuk solidaritas sosial dengan terbiasa berdiskusi dengan temanteman sekelompok kemudian berdiskusi dengan temanteman sekelasnya; (3) makin mengakrabkan guru dengan siswa; dan (4) ada kemungkinan suatu masalah harus diselesaikan siswa melalui eksperimen, hal ini juga akan membiasakan siswa dalam menerapkan metode eksperimen(Warsono \& Haryanto, 2012: 152).

Di samping pemilihan metode dan pendekatan pembelajaran, pemanfaatan media pembelajaran juga dapat membantu untuk menunjang tercapainya tujuan pembelajaran. Media dan teknologi pendidikan didefinisikan sebagai berikut: "educational technology is the study and ethical practice of facilitating learning and improving performance by creating, using, and managing appropriate technological processes and 
resource (AECT, 2004:1). Artinya bahwa teknologi pendidikan adalah studi dan pro ses memfasilitasi pembelajaran dan pengembangan tampilan melalui penciptaan, penggunaan dan pengaturan proses dan sumber daya secara teknologi yang tepat.

Pemanfaatan media dan teknologi dalam pembelajaran IPS bertujuan untuk dapat memperkuat pembelajaran. Pembelajaran IPS(social studies) yangkuat ditandai dengan ciriciri sebagai berikut: (1) bermakna bagi guru dansiswa; (2) integratif; (3) berdasarkan nilai; (4) menantang, dan (5) yang aktif (NCSS, (tt):37).Oleh sebab itu, media yang sesuai dengan tujuan pembelajaran IPS sa ngat diperlukan.

Penggunaan media dalam pembelajaran seperti powerpoint atau musik dapat mendukung penerapan strategi pembelajaran seperti presentasi, demonstrasi, latihan dan praktek, tutorial, diskusi, belajar kooperatif, permainan, simulasi, penemuan, dan penyelesaian masalah(Smaldino, Loether \& Russel, 2011: 2930). Meskipun dalam penggunaannya, media dan teknologi tidak terlepas dari kelebihan dan kekuaranganya untuk model pembelajaran.

Oleh karena itu, dengan penerapan PBLberbantuan media powerpoint dalam pembelajaran IPS diharapkan dapat meningkatkan aktivitas pembelajaran dan hasil belajar yang komprehensif. Hasil belajar mencakup aspek kognitif (pengetahuan), afektif (sikap) dan psikomotorik (keterampilan). Peningkatan aspek kognitif berupa peningkatan ketuntasan dalam belajar dan semakin berkurang siswa yang tidak tuntas belajar. Adapun peningkatan hasil belajar pada aspek afektif dan psikomotorik ditandai dengan peningkatan sikap dan keterampilan dalam bekerja sama dalam kelompok (teamwork skill).

Penelitian ini difokuskan pada dua masalah yaitu: (1) aktivitas guru dalam pembelajaran IPS rendah; dan (2) hasil belajar siswa mata pelajaran IPS rendah. Tujuan penelitian ini adalah: (1) menerapkan PBLberbantuan media powerpoint untuk meningkatkan aktivitas guru dalam pembelajaran IPS; dan (2) meningkatkan hasil belajar IPS siswa kelas
VIII SMP Negeri 1 Gemolong Kabupaten Sragen melalui penerapan PBL berbantuan media powerpoint.

Adapun beberapa manfaat penelitian ini dibedakan menjadi dua, yaitu manfaat secara teoretis dan manfaat secara praktis. Manfaat secara teoretis, meliputi: (a) untuk mendeskripsikan penerapan PBL berbantuan media powerpoint guna meningkatkan hasil belajar IPS; (b) untuk memprediksi peningkatan hasil belajar bila guru menggunakan PBL berbantuan media powerpoint dalam pembelajaran; (c) untuk mengendalikan penerapan PBL berbantuan media powerpoint untuk meningkatkan hasil belajar IPS. Adapun manfaat secara praktis, meliputi: (a) bagi siswa dapat meningkatkan hasil belajar IPS; (b) bagi peneliti dapat memberikan pengalaman dalam menerapkan PBL berbantuan media powerpoint untuk meningkatkan hasil belajarIPS; (c) bagi teman sejawatdapat menambah pengalaman dalam melaksanakan penelitian tindakan kelas; (c) bagi sekolahdapat meningkatkan mutu pembelajaran IPS, sehingga dapat membantu tercapainya tujuan pembelajaran di sekolah;dan (d) bagi perpustakaan sekolahdapat menambah koleksi karya ilmiah dalam bidang pendidikan dan pembelajaran.

\section{METODE}

Penelitian ini merupakan penelitian tindakan kelas (PTK).Dalam penelitian ini, peneliti dibantu oleh dua guru IPS di SMP Negeri 1 Gemolong Kabupaten Sragen sebagai kolaborator dan pelaksana tindakan. Penelitian dilaksanakan selama enam bulan antara bulan Agustus 2013 hingga Januari 2014. Alokasi waktu untuk penelitian se bagai berikut: (1) penyusunan proposal PTK dilaksanakan pada bulan Agustus 2013: (2) penyusunan instrumen penelitian dilaksanakan pada bulan September 2013; (3) pengumpulan data dilaksanakan dalam dua siklus, yaitu: (a) siklus I dilaksanakan pada tanggal 3, 10, 17, 24 Oktober tahun 2013; dan (b) siklus II dilaksanakan pada tanggal 14, 21, 28 bulan November, dan tanggal 5 Desember tahun 2013; (4) analisis data di- 
laksanakan pada pertengahan sampai akhir bulan Desember 2013; dan (5) penyusunan hasil laporan penelitian dilaksanakan pada akhir bulan Desember tahun 2013 hingga bulan Januari tahun 2014.

Tempat penelitian adalah SMP Negeri 1 Gemolong Kabupaten Sragen.Adapun subjek penelitian adalah siswa kelas VIIIC.

\section{Indikator Keberhasilan Tindakan}

Penelitian ini dianggap berhasil jika penerapan PBL berbantuan media powerpoint berhasil meningkatkan aktivitas pembelajaran dan hasil belajar. Secara rinci indikator keberhasilan tindakan dapat dijelaskan sebagai berikut: (1) terjadi peningkatan aktivitas pembelajaran dengan kriteria pencapai an pembelajaran $75 \%$ atau lebih; (2) terjadi peningkatan hasil belajar pada aspek kognitif (pengetahuan) berupa peningkatan nilai hasil ulangan harian setelah dilaksanakan tindakan, meliputi: (a) nilai siswa kategori sedang, baik dan sangat baik (lebih dari 70) mencapai lebih dari 75\%; dan (b) ketuntasan belajar mencapai 80\%; dan (3) terjadi peningkatan hasil belajar pada aspek afektif psikomotorik berupa berupa sikap siswa menerima dalam kerja sama kelompok, dan kete rampilan siswa dalam kerja sama kelompok rata-rata sebesar $65 \%$.

\section{Prosedur Penelitian}

Penelitian menggunakan tahaptahap dalam sebuah siklus penelitian meliputi: pe rencanaan tindakan, pelaksanaan tindakan, observasi, dan refleksi.Data yang diperlukan dalam penelitian ini meliputi data kuantitatif dan data kualitatif. Data kuantitatif berupa nilai ulangan harian siswa, sedangkan data kualitatif berupa data aktivitas guru dan siswa dalam pembelajaran.

Instrumen pengumpulan data yang digunakan meliputi: lembar observasi aktivitas guru dalam pembelajaran, lembar observasi aktivitas siswa dalam pembelajaran, pedoman wawancara dengan siswa, pedoman wawancara dengan guru, dan lembar soal tes tertulis. Dalam penelitian ini, teknik penelitian yang digunakan meliputi: dokumentasi, observasi, wawancara, dan tes tertulis.

\section{Teknik Analisis Data}

Data dalam penelitian ini dianalisis de ngan statistik deskriptif. Analisis ini untuk menjelaskan perkembangan proses pembelajaran dan hasil belajar sebelum dan setelah diterapkan pembelajaran dengan PBL.

Adapun langkahlangkah analisis data yang dilakukan meliputi: reduksi data, analisis data hasil belajar, menyusun dan penyajian data, membandingan data hasil belajar, dan menarik kesimpulan hasil penelitian.

\section{HASIL DAN PEMBAHASAN}

Beberapa data hasil penelitian penting yang diperoleh selama penelitian dapat dikelelompokkan menjadi dua bagian, yaitu data aktivitas pembelajaran dan data hasil belajar.

Data aktivitas pembelajaran meliputi data aktivitas pembelajaran yang diperoleh sebelum dilaksanakan tindakan (pra siklus) dan data hasil observasi aktivitas pembelajaran pada siklus I dan siklus II. Data aktivitas pembelajaran pra siklus yang berhasil diperoleh dapat dilihat pada tabel 1 .

Tabel 1. Data aktivitas guru dalam pembelajaran pra siklus

\begin{tabular}{ccc}
\hline No & Indikator & Persentase ketercapaian \\
\hline 1 & Perangkat pembelajaran & $30,00 \%$ \\
2 & Kegiatan awal & $30,00 \%$ \\
3 & Kegiatan inti & $30,88 \%$ \\
4 & Kegiatan penutup & $31,25 \%$ \\
\hline & Rata-rata & $30,53 \%$ \\
\hline
\end{tabular}


Berdasarkan data pada tabel 1 tersebut, penulis dapat menyimpulkan bahwa aktivitas pembelajaran pada pra siklus rendah. Kondisi tersebut dapat dilihat dari rata-rata ketercapaian dari empat variabel penilaian yang meliputi perangkat pembelajaran, kegiatan awal, kegiatan inti dan kegiatan penutup. Rata-rata dari keempat variabel penilaian tersebut sebesar 30,53\%.

Tabel 2. Hasil observasi aktivitas guru dalam pembelajaran siklus I

\begin{tabular}{ccc}
\hline No & Indikator & Persentase ketercapaian \\
\hline 1 & Perangkat pembelajaran & $85,00 \%$ \\
2 & Kegiatan awal & $90,00 \%$ \\
3 & Kegiatan inti & $92,65 \%$ \\
4 & Kegiatan penutup & $81,25 \%$ \\
\hline & Rata-rata & $87,22 \%$ \\
\hline
\end{tabular}

Setelah dilaksanakan tindakan pembelajaran IPS dengan menerapkan PBL berbantuan media powerpoint berupa penayangan gambargambar kerusakan lingkungan pada siklus I, peneliti memperoleh data aktivitas pembelajaran seperti terlihat pada tabel 2 . Data tersebut menunjukkan bahwa pencapaian rata-rata dari keempat variabel pe ngamatan aktivitas pembelajaran pada siklus I sebesar $87,22 \%$.

Berdasarkan analisis perbandingan data pada tabel 1 dan tabel 2, penulis dapat menyimpulkan bahwa terjadi peningkatan aktivitas pembelajaran dari pra siklus sebesar $30,53 \%$ menjadi $87,22 \%$ pada siklus I. Jadi, persentase peningkatannya sebesar $56,69 \%$ (dibulatkan menjadi 57\%).

Perkembangan peningkatan aktivitas pembelajaran dari pra siklus ke siklus I dapat dilukiskan dalam bentuk grafik seperti terlihat pada gambar 1 .

Gambar 1 Grafik perbandingan aktivitas pembelajaran pra siklus - siklus I

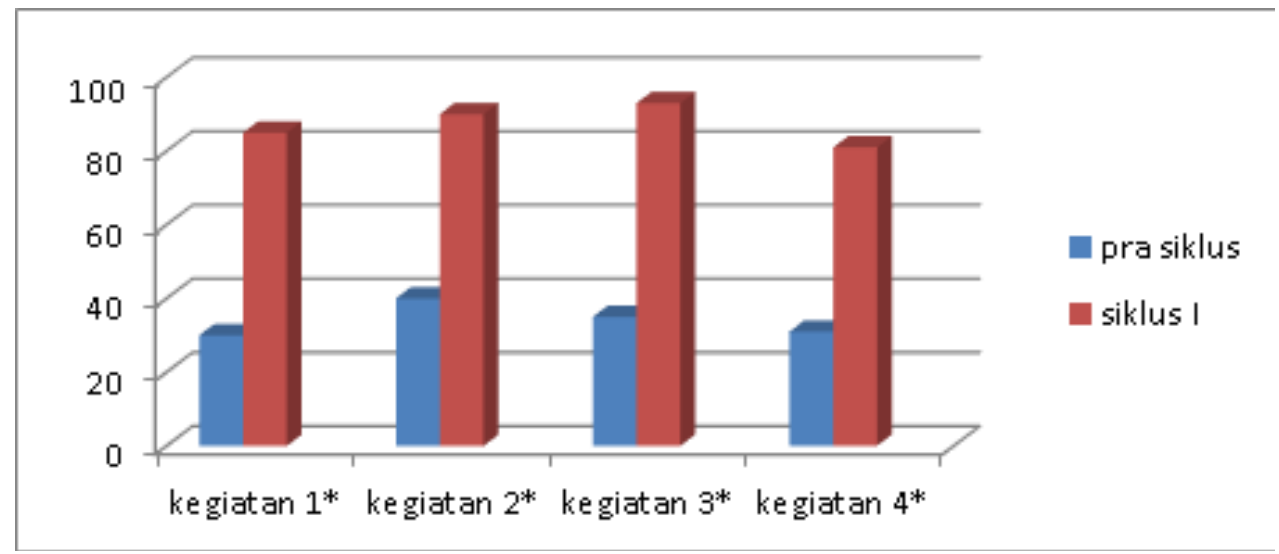

Keterangan *:

1. Persiapan perangkat pembelajaran

2. Kegiatan awal

3. Kegiatan inti

4. Kegiatan penutup 
Tabel 3. Hasil observasi aktivitas guru dalam pembelajaran siklus II

\begin{tabular}{ccc}
\hline No & Indikator & Persentase ketercapaian \\
\hline 1 & Perangkat pembelajaran & $95,00 \%$ \\
2 & Kegiatan awal & $90,00 \%$ \\
3 & Kegiatan inti & $97,06 \%$ \\
4 & Kegiatan penutup & $88,50 \%$ \\
\hline & Rata-rata & $92,39 \%$ \\
\hline
\end{tabular}

Selanjutnya, peneliti masih melakukan observasi terhadap aktivitas guru pada pembelajaran siklus II dengan menerapkan PBL berbantuan powerpoint berupa penayangan video mengenai dampak penyimpangan sosial. Data aktivitas pembelajaran tersebut dapat dilihat pada tabel 3. Berdasarkan data pada tabel tersebut, bahwa ketercapaian aktivitas pembelajaran pada siklus II rata-rata sebesar 92,39\%.

Berdasarkan analisis perbandingan data pada tabel 2 dan tabel 3 , peneliti menyimpulkan bahwa terjadi peningkatan aktivitas pembelajaran dari siklus I sebesar 87,22\% menjadi 92,39\% pada siklus II. Jadi, persentase peningkatannya sebesar 5,17\%. Perkembangan peningkatan aktivitas pembelajaran dari pra siklus ke siklus I dapat dilukiskan dalam bentuk grafik seperti terlihat pada gambar 2 .

\section{Gambar 2 Grafik perbandingan aktivitas pembelajaran siklus I - siklus II}

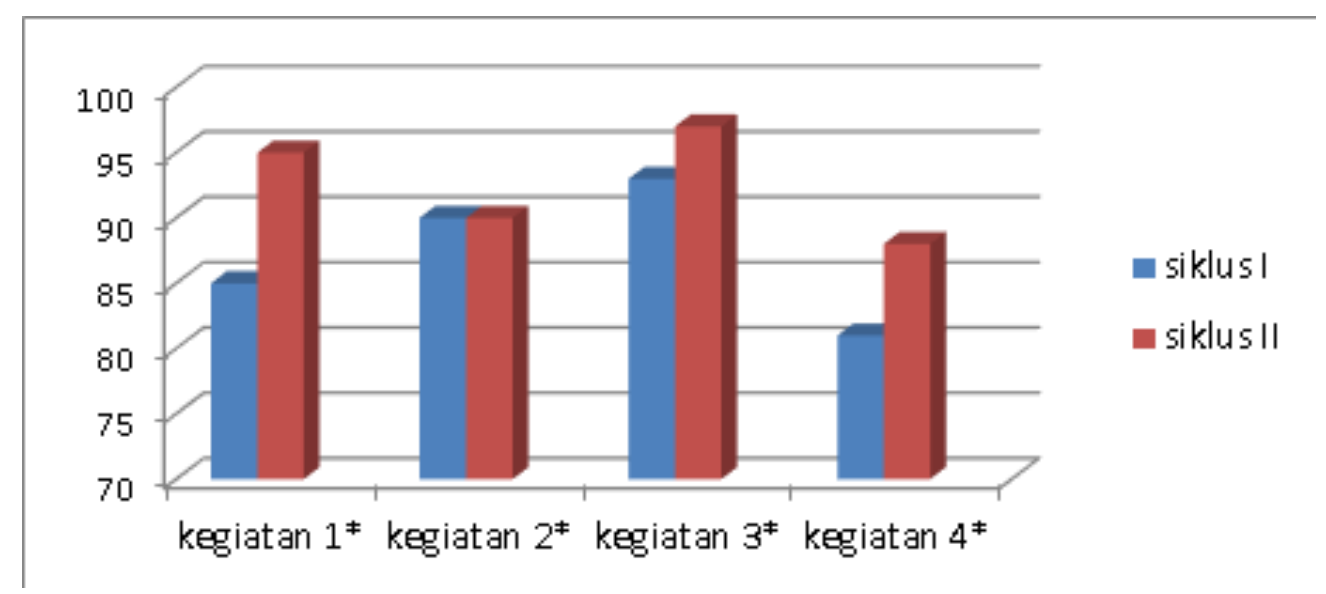

Keterangan *:

1. Persiapan perangkat pembelajaran

2. Kegiatan awal

3. Kegiatan inti

4. Kegiatan penutup

Data yang terkait dengan hasil belajar meliputi data hasil belajar aspek kognitif, afektif dan psikomotorik. Hasil belajar dari aspek kognitif berupa hasil ulangan harian, sedangkan aspek afektif dan psikomotorik berupa sikap

dan keterampilan kerja sama kelompok. Data hasil belajar pada aspek kognitif berupa hasil ulangan harian meliputi hasil ulangan harian pra siklus, siklus I dan siklus II. Sebagai data awal, peneliti menyajikan data hasil ulangan 
harian yang dilaksanakan sebelum tindakan dilaksanakan atau pra siklus. Data tersebut dapat dilihat pada tabel 4 .

Tabel 4. Hasil ulangan harian pra siklus

\begin{tabular}{llrcl}
\hline Nilai & $\mathrm{f}$ & $\%$ & Kualifikasi & \multicolumn{1}{c}{ Kategori } \\
\hline 9099 & 2 & 6,06 & $\mathrm{~A}$ & sangat baik \\
8089 & 2 & 6,06 & $\mathrm{~B}$ & baik \\
7079 & 7 & 21,21 & $\mathrm{C}$ & sedang \\
6069 & 12 & 36,36 & $\mathrm{D}$ & kurang \\
$<60$ & 10 & 30,30 & Gagal & sangat kurang \\
\hline Jml & 33 & 100 & & \\
\hline
\end{tabular}

Berdasarkan data pada tabel 4 tersebut, penulis dapat menarik kesimpulan bahwa jumlah persentase siswa yang memperoleh nilai kategori kurang dan sangat kurang cu- kup tinggi sebanyak 22 siswa atau sebesar $66,67 \%$, sedangkan siswa yang memperoleh nilai sedang, baik dan sangat baik hanya sebanyak 11 siswa atau sebesar 33,33\%.

Tabel 5. Ketuntasan belajar pra siklus

\begin{tabular}{cccccc}
\hline \multirow{2}{*}{ Jml Siswa } & \multicolumn{2}{c}{ Tuntas Belajar } & \multicolumn{2}{c}{ Tidak Tuntas Belajar } & KKM \\
& Jml & $\%$ & Jml & $\%$ & 75 \\
\hline 33 & 11 & 33,33 & 22 & 66,67 & 75 \\
\hline
\end{tabular}

Berdasarkan analisis data ulangan harian bahwa ketuntasan belajar pada pra siklus sebesar 33,33\% (KKM =75). Terdapat sebanyak 11 siswa telah tuntas belajar, sedangkan jumlah siswa yang tidak tuntas belajar seba nyak 22 siswa atau $66,67 \%$. Data ketuntasan belajar pada pra siklus dapat dilihat pada tabel 5.

Setelah selesai proses pembelajaran siklus I kemudian guru melakukan tes ulangan harian. Hasil ulangan harian pada siklus I tersebut dapat dilihat pada tabel 6 . Data tersebut menunjukkan bahwa jumlah siswa yang memperoleh nilai kategori sedang, baik dan sangat baik sebanyak 26 siswa atau sebesar 78,79\%, sedangkan siswa yang memperoleh nilai kurang dan sangat kurang sebanyak 7 siswa atau sebesar 21,21\%. 
Tabel 6. Hasil ulangan harian siklus I

\begin{tabular}{lcccl}
\hline Nilai & F & $\%$ & Kualifikasi & \multicolumn{1}{c}{ Kategori } \\
\hline 9099 & 11 & 33,33 & A & sangat baik \\
8089 & 12 & 36,36 & B & baik \\
7079 & 3 & 9,09 & C & sedang \\
6069 & 2 & 6,06 & D & kurang \\
$<60$ & 5 & 15,15 & Gagal & sangat kurang \\
\hline Jml & 33 & 100 & & \\
\hline
\end{tabular}

Tabel 7. Data ketuntasan belajar siklus I

\begin{tabular}{cccccc}
\hline \multirow{2}{*}{ Jml Siswa } & \multicolumn{2}{c}{ Tuntas Belajar } & \multicolumn{2}{c}{ Tidak Tuntas Belajar } & KKM \\
& Jml & $\%$ & Jml & $\%$ & 75 \\
\hline 33 & 23 & 69,70 & 10 & 30,30 & \\
\hline
\end{tabular}

Berdasarkan analisis data ulangan harian, ketuntasan belajar pada siklus I sebesar 69,70\%. Hasil analisis tersebut menunjukkan bahwa terdapat sebanyak 23 siswa telah tuntas belajar, sedangkan jumlah siswa yang tuntas belajar sebanyak 10 siswa atau 30,30\%. Data ketuntasan belajar pada siklus I dapat dilihat pada tabel 7.

\section{Gambar 3 Perbandingan hasil ulangan harian pra siklus - siklus I}

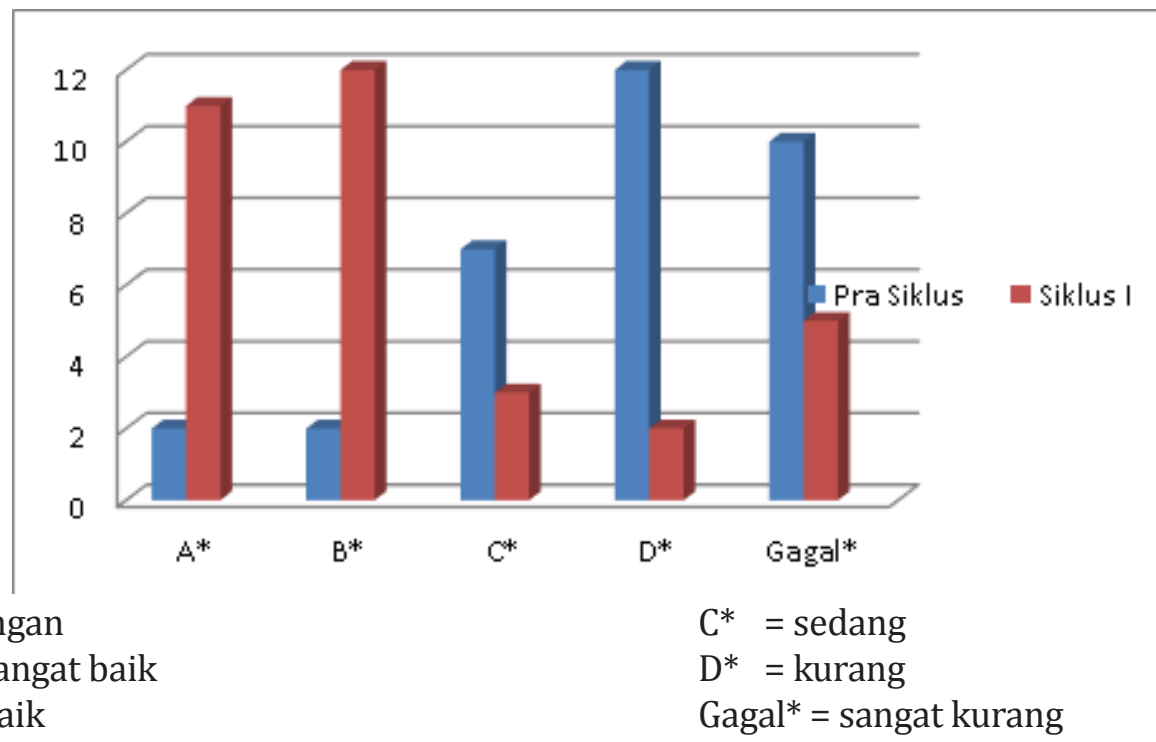


Berdasarkan analisis perbandingan data pada tabel 4 dan tabel 6, penulis dapat menyimpulkan bahwa terjadi peningkatan hasil belajar dari pra siklus ke siklus I. Pada pra siklus, jumlah siswa yang memperoleh nilai kategori sedang, baik dan sangat baik sebanyak 11 siswa atau sebesar 33,33\%, sedangkan pada siklus I jumlahnya menjadi 26 siswa atau sebesar 78,79\%. Jadi, peningkatannya sebesar $57,58 \%$. Peningkatan hasil belajar tersebut dapat dilukiskan dalam bentuk grafik seperti terlihat pada gambar 3 .
Di samping itu, berdasarkan analisis perbandingan data hasil ulangan harian juga menunjukkan terjadi peningkatan ketuntasan belajar dari pra siklus ke siklus I. Jumlah siswa yang tuntas belajar pada pra siklus sebanyak 11 siswa atau sebesar 33,33\%, sedangkan pada siklus I sebanyak 23 siswa atau sebesar $66,67 \%$. Jadi, peningkatannta sebesar sebesar $33,37 \%$. Perkembangan ketuntasan belajar pada pra siklus - siklus I dilukiskan dalam sebuah grafik yang dapat dilihat pada gambar 4 .

\section{Gambar 4. Grafik perkembangan ketuntasan belajar pra siklus - siklus I}

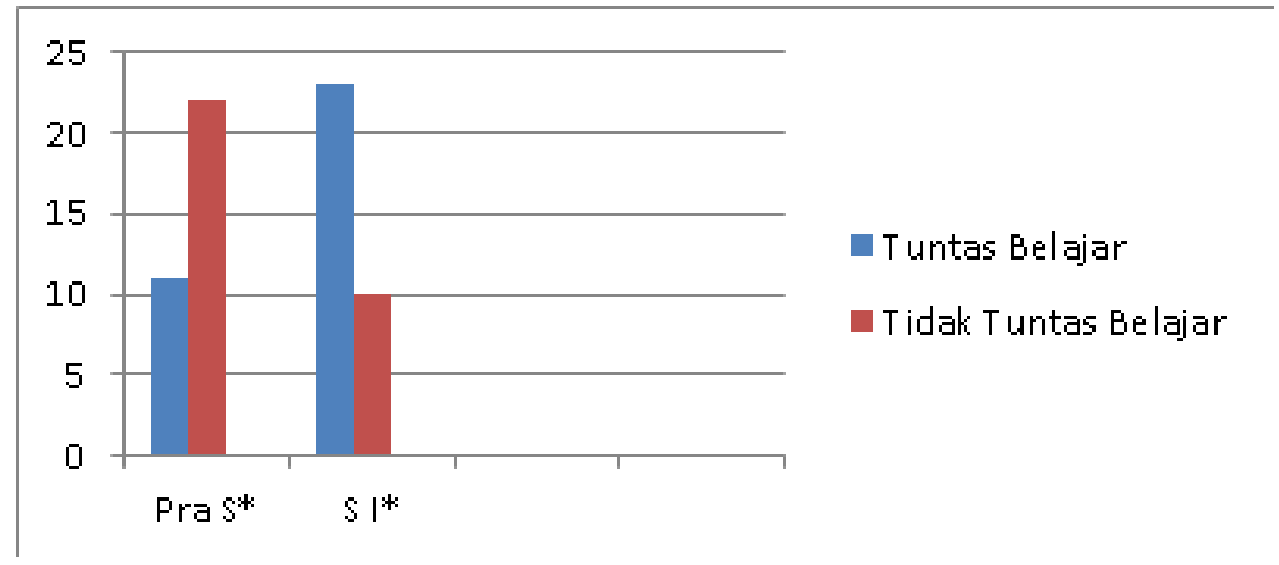

Keterangan:

Pra S* = Pra Siklus

S I* = Siklus I

Setelah dilakukan tindakan pembelajaran pada siklus II, guru melakukan ulangan harian dan hasil ulangan tersebut dapat dilihat pada tabel 8. Berdasarkan data tersebut, penulis dapat menjelaskan bahwa persentase siswa yang memperoleh nilai sedang, baik dan sangat baik sebanyak 28 siswa atau sebesar
$84,85 \%$, sedangkan siswa yang memperoleh nilai kurang dan sangat kurang sebanyak 5 siswa sebesar $15,15 \%$.

Analisis terhadap data ulangan harian siklus II menunjukkan bahwa ketuntasan belajar tercapai sebesar $81,82 \%$. Hasil analisis secara rinci sebagai berikut: sebanyak 27 siswa telah tuntas belajar, dan siswa yang tidak tuntas belajar sebanyak 6 siswa atau 18,18\%. Data ketuntasan belajar pada siklus II dapat dilihat pada tabel 9. 
Tabel 8. Hasil ulangan harian siklus II

\begin{tabular}{ccccl}
\hline Nilai & $\mathrm{f}$ & $\%$ & Kualifikasi & \multicolumn{1}{c}{ Kategori } \\
\hline 9099 & 18 & 55,55 & $\mathrm{~A}$ & sangat baik \\
8089 & 8 & 24,24 & $\mathrm{~B}$ & baik \\
7079 & 2 & 6,06 & $\mathrm{C}$ & sedang \\
6069 & 2 & 6,06 & $\mathrm{D}$ & kurang \\
$<60$ & 3 & 9,09 & Gagal & sangat kurang \\
\hline Jml & 33 & 100 & & \\
\hline
\end{tabular}

Tabel 9. Data ketuntasan belajar siklus II

\begin{tabular}{cccccc}
\hline \multirow{2}{*}{ Jml Siswa } & \multicolumn{2}{c}{ Tuntas Belajar } & \multicolumn{2}{c}{ Tidak Tuntas Belajar } & KKM \\
& Jml & $\%$ & Jml & $\%$ & 75 \\
\hline 33 & 27 & 81,82 & 6 & 18,18 & 75 \\
\hline
\end{tabular}

Gambar 5 Perbandingan hasil ulangan harian siklus I dan siklus II

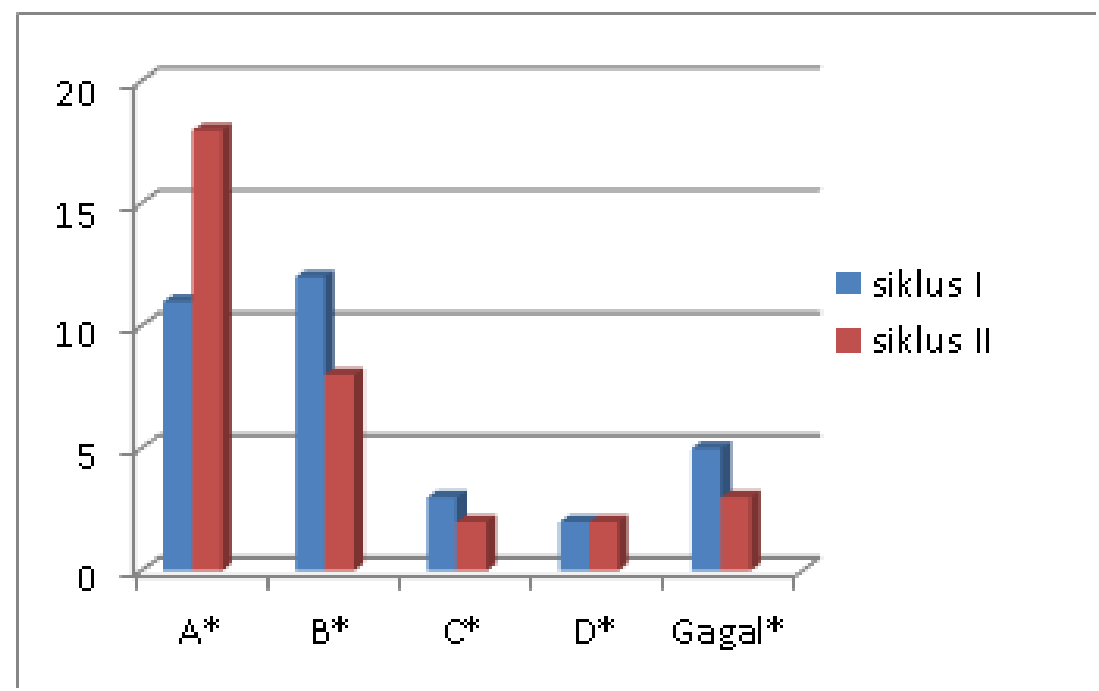

Keterangan

$\mathrm{A}^{*}$ = sangat baik

$\mathrm{B}^{*}=$ baik

$\mathrm{C}^{*}=$ sedang

$\mathrm{D}^{*}=$ kurang

Gagal $^{*}=$ sangat kurang
Berdasarkan analisis perbandingan data pada tabel 6 dan tabel 8, peneliti menyimpulkan bahwa terjadi peningkatan hasil belajar dari siklus I sebesar 78,79\% menjadi 84,85\% pada siklus II. Jadi, peningkatannya sebesar 6,06\%. Peningkatan hasil belajar tersebut dapat dilukiskan dalam bentuk grafik seperti terilihat pada gambar 5 . 
Di samping itu, analisis perbandingan data hasil ulangan juga menunjukkan pe ningkatan ketuntasan belajar dari siklus I ke siklus II. Jumlah nilai yang tuntas pada siklus I sebanyak 23 siswa atau sebesar 69,70\%, se- dangkan nilai yang tuntas pada siklus II sebanyak 27 siswa atau sebesar $81,82 \%$. Jadi, peningkatannya sebesar $12,12 \%$. Perkembangan ketuntasan belajar pada siklus I dan siklus II dapat dilihat pada gambar 6 .

\section{Gambar 6. Grafik perkembangan ketuntasan belajar siklus I - siklus II}

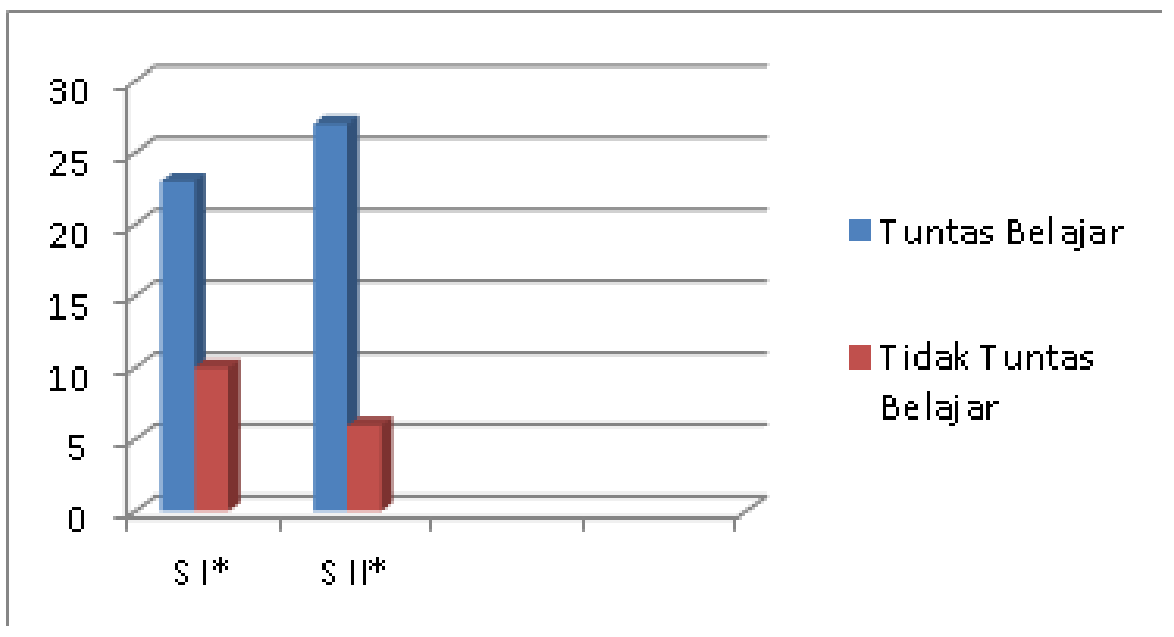

Keterangan:

$\mathrm{S} \mathrm{I}^{*}=$ Siklus I

S II* = Siklus II

Data hasil belajar yang terkait dengan sikap dan keterampilan kerja sama kelompok diperoleh melalui observasi aktivitas siswa dalam pembelajaran pada siklus I dan siklus II. Data mengenai sikap dan keterampilan kerja sama kelompok dilihat dari penilaian enam indikator pengamatan dan penilaian secara individu.

Data mengenai sikap dan keterampilan kerja sama kelompok dilihat dari rata-rata enam indikator pengamatan pada siklus I dapat dilihat pada tabel 10. Berdasarkan data tersebut, peneliti menyimpulkan bahwa dilihat dari rata-rata keenam indikator pengamatan adalah sebesar 71,46\%. Pencapaian persentase tersebut masih tergolong rendah, karena masih di bawah 75\%. 
Tabel 10. Hasil observasi aktivitas siswa berdasarkan penilaian enam indikator pengamatan pada siklus I

\begin{tabular}{ccrc}
\hline No & Indikator Penilaian & Pencapaian Skor & $\%$ \\
\hline 1 & Indikator 1* & 103 & 78,03 \\
2 & Indikator 2* & 102 & 77,27 \\
3 & Indikator 3* & 80 & 60,61 \\
4 & Indikator 4* & 100 & 75,76 \\
5 & Indikator 5* & 93 & 70,45 \\
6 & Indikator 6* & 88 & 66,67 \\
\hline \multicolumn{5}{c}{ Rata-rata }
\end{tabular}

Keterangan*:

1. Sikap mau menerima semua anggota kelompok

2. Berkomunikasi secara intensif dengan memperhatikan anggota kelompok yang sedang berbicara

3. Memberikan berbaga'i informasi pada saat kerja kelompok berlangsung

4. Menerima berbagai informasi pada saat kerja kelompok berlangsung

5. Turut serta memberikan pendapat/ide pada saat kerja kelompok, membuat laporan tertulis, dan diskusi

6. Mendorong teman untuk mengerjakan tugas dalam kerja kelompok

Tabel 11. Hasil observasi aktivitas siswa dalam pembelajaran siklus I berdasarkan kelompok individu

\begin{tabular}{cclcc}
\hline Skor & Kualifikasi & \multicolumn{1}{c}{ Kategori } & f & $\%$ \\
\hline 9099 & A & sangat baik & 4 & 12,12 \\
8089 & B & baik & 6 & 18,18 \\
7079 & C & sedang & 4 & 12,12 \\
6069 & D & kurang & 8 & 24,24 \\
$<60$ & Gagal & sangat kurang & 11 & 33,33 \\
\hline Jumlah & & & 33 & 100 \\
\hline
\end{tabular}

Berdasarkan pada tabel 10 tersebut, selanjutnya data dianalisis dan dikelompokan sesuai dengan pencapaian skor penilaian tiaptiap individu pada siklus I, peneliti me ngelompokkan siswa kelompok yang termasuk kategori sedang, baik dan sangat baik sebanyak 14 siswa atau sebesar $42,42 \%$, sedangkan kelompok siswa yang memperoleh penilaian sikap dan keterampilan kelompok pada kategori kurang dan sedang sebanyak
19 siswa atau sebesar 57,58\%. Hasil pengelompokkan siswa tersebut dapat dilihat pada tabel 11.

Selanjutnya, data hasil observasi aktivitas siswa dalam pembelajaran pada siklus II dapat dilihat pada tabel 12.Data tersebut menunjukkan bahwa rata-rata persentase pencapaian sikap dan keterampilan kerja sama kelompok pada siklus II sebesar $77,27 \%$. 
berdasarkan data pada tabel 12 tersebut,peneliti menganalisis dan dikelompokan sesuai dengan pencapaian skor penilaian tiaptiap individu. Pada siklus II, kelompok siswa yang termasuk kategori sedang, baik dan sangat baik sebanyak 22 siswa atau sebesar 66,67\%, sedangkan kelompok siswa yang termasuk kategori kurang dan sedang sebanyak 11 siswa atau sebesar 33,33\%. Hasil pengelompokkan siswa tersebut dapat dilihat pada tabel 13.

\section{Tabel 12. Hasil observasi aktivitas siswa berdasarkan penilaian enam indikator pengamatan pada siklus II}

\begin{tabular}{cccc}
\hline No & Indikator Penilaian & Pencapaian Skor & $\%$ \\
\hline 1 & Indikator 1* & 107 & 81,06 \\
2 & Indikator 2* $^{*}$ & 120 & 90,91 \\
3 & Indikator 3* $^{*}$ & 94 & 71,21 \\
4 & Indikator 4* & 105 & 79,55 \\
5 & Indikato r 5* & 95 & 71,97 \\
6 & Indikator 6* & 91 & 68,94 \\
\hline \multicolumn{5}{c}{ Rata-rata }
\end{tabular}

Keterangan*:

1. Sikap mau menerima semua anggota kelompok

2. Berkomunikasi secara intensif dengan memperhatikan anggota kelompok yang sedang berbicara

3. Memberikan berbagai informasi pada saat kerja kelompok berlangsung

4. Menerima berbagai informasi pada saat kerja kelompok berlangsung

5. Turut serta memberikan pendapat/ide pada saat kerja kelompok, membuat laporan tertulis, dan diskusi

6. Mendorong teman untuk mengerjakan tugas dalam kerja kelompok

Tabel 13. Hasil observasi aktivitas siswa dalam pembelajaran siklus II

\begin{tabular}{lclcc}
\hline Skor & Kualifikasi & \multicolumn{1}{c}{ Kategori } & f & $\%$ \\
\hline 9099 & A & sangat baik & 8 & 24,24 \\
8089 & B & baik & 6 & 18,18 \\
7079 & C & sedang & 8 & 24,24 \\
6069 & D & kurang & 10 & 30,30 \\
$<60$ & Gagal & sangat kurang & 1 & 3,03 \\
\hline Jumlah & & & 33 & 100 \\
\hline
\end{tabular}

Selanjutnya, berdasarkan hasil analisis perbandingan data pada tabel 11 dan tabel 13, peneliti dapat mengambil kesimpulan bahwa terjadi peningkatan sikap dan kete rampilan kerja sama kelompok dari siklus I sebesar $42,42 \%$ menjadi $66,67 \%$ pada siklus II. Jadi, persentase peningkatannya sebesar 24,24\%. Perkembangan sikap dan kete 
rampilan kerja sama kelompok tersebut dapat dilukiskan dalam bentuk grafik seperti terlihat pada gambar 7 .

\section{Gambar 7 Grafik perbandingan aktivitas siswa pada siklus I - siklus II}

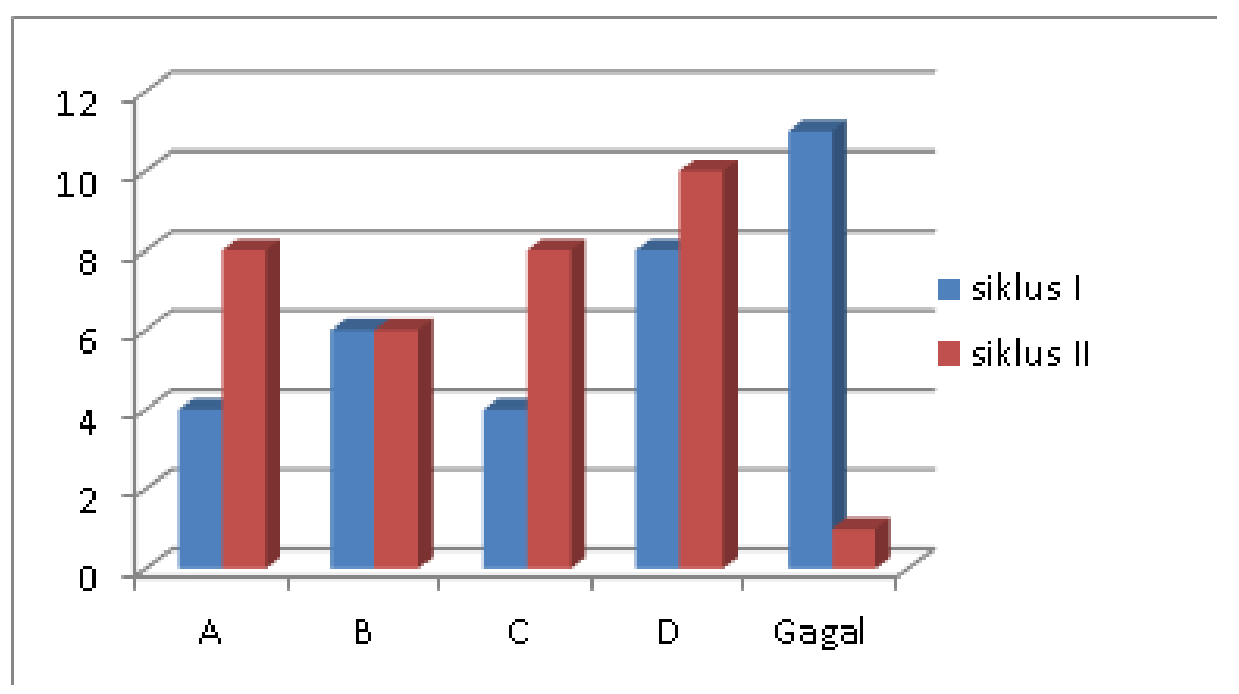

\section{SIMPULAN}

Pembelajaran dengan menerapkan PBL berbantuan media powerpoint dapat meningkatkan aktivitas pembelajaran dan hasil belajar IPS pada siklus I dan siklus II. Peningkatan aktivitas pembelajaran ditunjukkan adanya peningkatan persentase sebesar $57 \%$ pada siklus I setelah diterapkan pembelajaran dengan pendekatan PBL berbantuan media powerpoint berupa gambar kerusakan lingkungan hidup. Aktivitas pembelajaran juga masih mengalami peningkatan sebesar 5\% setelah diterapkan pembelajaran PBL berbantuan media powerpoint dengan penayangan video tentang dampak penyimpangan sosial.

Dampak positif dari penerapan PBL berbantuan media powerpoint juga ditunjukkan pada hasil belajar siswa pada aspek kognitif, afektif dan psikomotorik. Peningkatan hasil belajar pada aspek kognitif ditunjukkan oleh peningkatan kualitas hasil belajar dan ketuntasan belajar. Setelah penerapan PBL berbantuan media powerpoint pada siklus I, hasil belajar meningkat sebesar 57,58\% dan ketuntasan belajar sebesar 36,37\%. Hasil belajar ini juga masih mengalami peningkatan setelah tindakan pada siklus II, yaitu peningkatan hasil belajar sebesar 6,06\% dan ketuntasan belajar sebesar $12,12 \%$.

Selain itu, penerapan PBL berbantuan media powerpoint juga dapat meningkatkan hasil belajar berupa sikap dan keterampilan kerja sama siswa. Berdasarkan hasil perbandingan sikap dan keterampilan kerja sama kelompok antara siklus I dan siklus II, persentase peningkatannya sebesar $24,24 \%$.

Penerapan PBL berbantuan media power point terbukti telah dapat meningkatkan hasil belajar siswa secara komprehensif. Oleh karena itu, peneliti menyarankan kepada para pendidik untuk menerapkan pendekatan PBL untuk tema pembelajaran dan memanfaatkan media pembelajaran yang tepat seperti media powerpoint, sehingga tujuan pembelajarandapat tercapai. Lebih lanjut, peneliti menghimbau kepada para pendidik dan pengembang teori dan praktik pembelajaran, serta melakukan penelitian lebih lanjut untuk mengembangkan metode ini. Akhirnya, peneliti berharap kepada semua pihak atas kritik dan sarannya untuk kesempurnaan tulisan ini.Semoga tulisan ini bermanfaat bagi pembaca. 


\section{UCAPAN TERIMA KASIH}

Dalam penulisan artikel jurnal ini, penulis sangat dibantu oleh banyak pihak khususnya dosen pembimbing. Untuk itu, dalam kesempatan ini penulis menyampaikan terima kasih kepada yang terhormat Pembimbing tesis, yang telah banyak membantu, mengarahkan dan membimbing sehingga artikel jurnal ini dapat terselesaikan.

\section{DAFTAR PUSTAKA}

AECT.1994. The definition of Educational Technology. Diakses pada tanggal 21 Janu ari 2013 dari ocw.metu.edu.tr/file.php.

Bidang DIKBUD KBRI Tokyo.UndangUndang Nomor 20 Tahun 2003 Tentang Sistem Pendidikan Nasional. Diakses pada tanggal 9 April 2013 dari www.inherentdikti. net/files/sisdiknas.pdf

De Graaff, E., \& Kolmos, A. 2003.Characteris tics of ProblemBased Learning.In Int. J. Engng Ed. Vol. 19, No. 5, pp. 657 \pm 662 . Diakses pada tanggal 7 Mei 2013 dari www. ijee.ie/articles/Vol195/IJEE1450.pdf

Jones, R. D. 2009. Student Engagement Teacher Handbook. New York: International Center for Leadership in Education.

Muchith. 2008. Pembelajaran Kontekstual. (Cetakan pertama). Semarang: RaSAIL.

NCSS.Using Technology for Powerful Social Studies Learning.Diakses pada tanggal 24 April 2013 dari annenbergmedia.org.
Newman, M. J. 2005. Problem Based Learning: An Introduction and Overview of TheKey Features of the Approach. Journal of Veteri nary $p$. 1220.Diakses pada tanggal $13 \mathrm{Mei}$ 2013 dariwww.utpjournals.com/jvme/ tocs/321/12.pdf.

Rusman. 2012. ModelModel Pembelajaran: Mengembangkan Profesionalisme Guru. Jakarta: PT. RajaGrafindo Persada. Edisi kedua.

Savery, J. R. 2006. Overview of ProblemBased Learning: Definitions and Distinctions. Interdisciplinary Journal of ProblembasedLearning, 1(1).Diakses pada tanggal 16 Juni 2013 dari docs.lib.purdue.edu/ cgi/viewcontent.cgi?...ijpbl.

Smaldino, S. E., Lowther D. L., \& Russell J. D. 2009.Instructional Technology \&Media for Learning. (Terjemahan Arif Rahman). Jakarta: Kencana. Edisi 9 cetakan pertama.

Tambahan Lembaran Negara Republik Indonesia Nomor 4496. Peraturan Pemerin tahun Nomor 19 Tahun 2005 Tentang Standar Nasional Pendidikan.Diakses pada tanggal 9 April 2013 dari https:// akhmadsudrajat.files.wordpress.com.

Warsono \& Hariyanto.2012. Pembelajaran Aktif Teori Dan Assesment. Bandung: PT. Remaja Rosdakarya. Cetakan pertama

Wibowo, A. 2012.Menjadi guru berkarakter. Yogyakarta: Pustaka Pelajar. Cetakan pertama. 